\title{
Geotechnical Assessment of the Foundation of Housing Chamber of Yaragol Gravity Dam, Karnataka State, India
}

A.K. Naithani, L.G. Singh, Prasnna Jain and D.S. Rawat

National Institute of Rock Mechanics, Bengaluru, India

\begin{abstract}
Aim: Geotechnical assessment of the foundation including engineering geological investigations are essential for important civil structures to provide permanent data set for geological interpretations and for recommendations of suitable engineering measures for the improvement of the foundation. Yaragol Gravity Dam for drinking water is being constructed across Markandaya river in Karnataka State of India. Engineering geological mapping on 1:200 scale was carried out for Housing Chamber of Yaragol Gravity Dam to evaluate the design basis foundation parameters. $2 \mathrm{~m}$ x $2 \mathrm{~m}$ grids were prepared for mapping of the floor. Based on the field observations and evidences, it was found that the floor area consists of foliated gneiss and granite. No evidence of faulting or shearing was observed on the surface of the floor area. Geotechnical assessment of the foundations was done on the basis of detailed engineering geological mapping and laboratory test results. Classification of rock mass using Rock Mass Rating (RMR) of Bieniawski (1989) has been attempted and based on investigations recommendations for the treatment of foundation were given. Rock type and Rock Mass Rating (RMR) methods were used for assessing the safe bearing pressure of the foundation. Consolidation grouting up to $6 \mathrm{~m}$ depth in the foundation using primary at $6 \mathrm{~m}$ spacing and secondary holes at $3 \mathrm{~m}$ spacing was recommended. After detailed investigations it was found that, the foundation is suitable to locate a housing chamber.
\end{abstract}

Keywords: Engineering geology; gravity dam; housing foundation; grouting

\section{Introduction}

Yaragol Gravity Dam (YGD) for drinking water storage across Markandaya river in Karnataka State of India is being constructed. The main components of the project are: $164.850 \mathrm{~m}$ long left concrete non-overflow dam, 136.500 $\mathrm{m}$ long central concrete overflow spillway dam, $112.690 \mathrm{~m}$ long right concrete non-overflow dam and $12.6 \mathrm{~m} \times 16.8 \mathrm{~m}$ housing chamber. Maximum height of the dam will be $38.10 \mathrm{~m}$ from the deepest foundation level. Ogee spillway with crest level at RL $691.60 \mathrm{~m}$ will be constructed for a length of $136.50 \mathrm{~m}$ in the river course sandwiched between the left and right concrete non-overflow dam. The spillway is designed to dispose of the maximum designed flood discharged of 482.73 cumecs. The top bund level of the structure is proposed at RL $694.10 \mathrm{~m}$ with a top width of $6.0 \mathrm{~m}$ and maximum bottom width is $24.00 \mathrm{~m}$. The non-overflow section is designed with a slope of 1:10 and 0.85:1 below the RL $680.0 \mathrm{~m}$ on upstream and RL $687.00 \mathrm{~m}$ on the downstream sides respectively.

This project will cater to the drinking water needs of 45 en-route villages and 3 towns namely Kolar, Bangarpet and Malur of Kolar district, which are having the recurring drought problems and shortage of drinking water. The water requirement of these towns and villages is about $500 \mathrm{Mcft}$ and the dam gross capacity will also be $500 \mathrm{Mcft}$. This paper deal with the geotechnical assessment of the foundation of housing chamber. Suitable engineering measures for the treatment of foundation based on geotechnical assessment are recommended. Detailed engineering geological mapping on 1:200 scale was carried out using the Total Station and a total area of approximately 340 sq.m. was mapped. Core

Copyright (C) 2018 Yaragol Gravity Dam et al.

doi: $10.18063 / \mathrm{nn} . \mathrm{v} 2 \mathrm{i} 1.396$

This is an open-access article distributed under the terms of the Creative Commons Attribution Unported License

(http://creativecommons.org/licenses/by-nc/4.0/), which permits unrestricted use, distribution, and reproduction in any medium, provided the original work is properly cited. 
samples were tested for the uniaxial compressive strength and assessment of the safe bearing pressure of the foundation was done based on rock type and rock mass rating classification.

Housing chamber of $12.6 \mathrm{~m} \times 16.8 \mathrm{~m}$ dimension is being constructed at non-overflow section between Chainage $139.85 \mathrm{~m}$ to $165.85 \mathrm{~m}$. Overall height of the structure is $43.0 \mathrm{~m}$ from raft top level (RL $+660 \mathrm{~m}$ ) to roof level (RL $+703.40 \mathrm{~m}$ ). Series of pumps are proposed to be installed at $694.1 \mathrm{~m}$ level i.e. at $34.1 \mathrm{~m}$ from the raft level. Thickness of raft proposed is $1000 \mathrm{~mm}$. RCC steining wall is proposed on all sides except at water entry side to housing chamber. Height of wall is $7.0 \mathrm{~m}$ from the top of raft. 2:1 slope is proposed beyond $7.5 \mathrm{~m}$ upto NGL with pitching.

\section{Material and Methods}

Grids were prepared for engineering geological mapping of the housing chamber floor area. The size of the grid was $2 \mathrm{~m} \times 2 \mathrm{~m}$, which was decided based on the mapping accuracy and resolution required for such investigations. Grids for mapping were marked on the floor by surveyor using elevation \& chainages. Detailed examination of rock types in each grid was carried out which includes mineralogical composition, texture, classification and nomenclature and degree/grade of weathering. The attitude and structure of the rocks, fractures and joint pattern present in the floor was determined for mapping. ISRM (1978), classifications for weathered rock mass was used to characterize the rock mass into different grade. The assessment of Rock Mass Rating (Bieniawski, 1989) for granite gneiss rock masses, based on the rock joints and their nature and laboratory test data was done. Assessment of the safe bearing pressure of the foundation was done from rock types and rock mass rating.

\section{Engineering Geological and Geotechnical Assessment}

Foundation floor engineering geological mapping is essential for important civil structures to provide permanent data set for geological interpretations during construction and also it forms valuable documentation for post-construction stage (Naithani et al. 2016, 2017). For very important structure, the supporting foundation strata should be studied and documented to provide data for credible geologic interpretations (Harikumar, 2010). Shallow foundations cover such types of foundations in which load transfer is through direct bearing pressure of the bearing strata. Rock is recognized as the best foundation material. However, design engineers should be aware of the dangers associated with heterogeneity and unfavourable rock conditions since over stressing a rock foundation may result in large differential settlements or perhaps sudden failure (Naithani and Singh, 2016).

In order to evaluate the design basis foundation parameters for housing chamber, engineering geological mapping was carried out by on 1:200 scale (Figure 1). All the discontinuities in the rock mass of foundation of housing chamber with the zone of influence of the foundation has been identified and mapped. The primary purpose of the mapping is to provide a permanent record of conditions during the excavation. Mapping will be used to assess the requirement of any ground improvement. This permanent foundation record will assist in making better interpretation of post-construction foundation instrumentation data. 


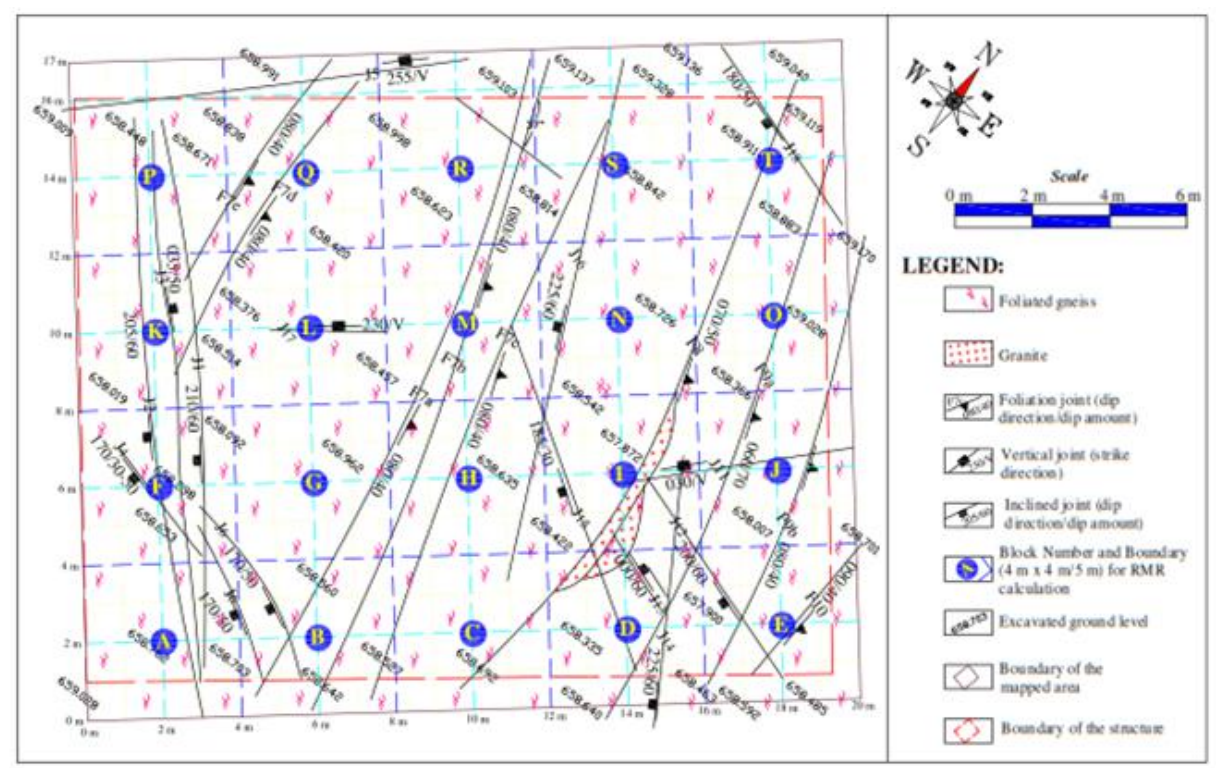

Figure. 1; Geological plan map of the housing chamber foundation.

The foundation of housing chamber will be resting as per design on a raft of $1000 \mathrm{~mm}$ thick at about $17.0 \mathrm{~m}$ below the existing ground level for functional requirement. The design foundation level is at RL +659.00 but in some areas, it is excavated up to an average $\mathrm{RL}+658.67$ and the over excavation recorded is up to $1.128 \mathrm{~m}$ because of presence of unfavourable discontinuities and blasting. Based on the field observations and evidences, it was found that the entire floor area consists of fine to medium grained, hard and jointed foliated gneiss and granite. These rocks are belonging to Younger Gneiss Complex Group range in age from 2.6 to 3.0 b.y. (Radhakrishna and Vaidyanadhan, 2011). No shear zone or evidences of faulting were observed on the surface of floor area. The structural features observed during the mapping indicated the need for consolidation grouting so that the entire floor area function as single rock mass.

Foliated gneiss and granite are fine to medium grained, hard and jointed. Main minerals composition is feldspars, quartz and mica. The rock mass is characterized by prominent three number of joint sets, which are continuous and persistent, rough to smooth with unaltered joint walls (Table 1). Staining has been recorded along the joint surfaces where the joints are tight and where opening is up to $20.0 \mathrm{~mm}$, weathered material and crushed material filling has been recorded. In general, the rock mass is characterized by dry condition or minor inflow i.e. $<5.01 / \mathrm{min}$.

\begin{tabular}{|c|c|c|c|c|c|c|c|c|c|}
\hline Joint No. & $\begin{array}{l}\text { Strike/Dip } \\
\text { Direction }\end{array}$ & $\begin{array}{l}\text { Dip } \\
\text { amou } \\
\text { nt }\end{array}$ & $\begin{array}{l}\text { Spacin } \\
\mathrm{g}(\mathrm{cm})\end{array}$ & $\begin{array}{l}\text { Persisten } \\
\text { ce }(m)\end{array}$ & $\begin{array}{l}\text { Apertu } \\
\text { re } \\
(\mathrm{mm})\end{array}$ & $\begin{array}{l}\text { Roughne } \\
\text { ss }\end{array}$ & Infilling & $\begin{array}{l}\text { Weatheri } \\
\text { ng }\end{array}$ & $\begin{array}{l}\text { Grou } \\
\text { nd } \\
\text { Water }\end{array}$ \\
\hline $\mathrm{J} 1$ & 210 & 60 & $60-250$ & $>20$ & $10-20$ & $\begin{array}{l}\text { Rough, } \\
\text { Undulatin } \\
\text { g }\end{array}$ & $\begin{array}{l}\text { Weathered } \\
\text { material }\end{array}$ & SW & Dry \\
\hline $\mathrm{J} 2$ & 205 & 60 & $\begin{array}{l}\text { Rando } \\
\mathrm{m}\end{array}$ & $>20$ & $10-20$ & $\begin{array}{l}\text { Rough, } \\
\text { Undulatin } \\
\text { g }\end{array}$ & $\begin{array}{l}\text { Weathered } \\
\text { material }\end{array}$ & SW & Dry \\
\hline $\mathrm{J} 3$ & 035 & 50 & $60-250$ & $>20$ & $10-20$ & $\begin{array}{l}\text { Smooth, } \\
\text { Undulatin } \\
\mathrm{g}\end{array}$ & $\begin{array}{l}\text { Weathered } \\
\text { material }\end{array}$ & SW & Dry \\
\hline $\mathrm{J} 4$ & 170 & $30-50$ & $20-60$ & $<5$ & Tight-5 & $\begin{array}{l}\text { Rough, } \\
\text { Undulatin } \\
\mathrm{g}\end{array}$ & $\begin{array}{l}\text { Fragments } \\
\text { of biotite/mi } \\
\text { ca }\end{array}$ & Fresh & Dry \\
\hline J5 & 225 & Vertic & 50 & $>20$ & $10-20$ & Rough, & Weathered & Fresh & Dry \\
\hline
\end{tabular}




\begin{tabular}{|c|c|c|c|c|c|c|c|c|c|}
\hline Joint No. & $\begin{array}{l}\text { Strike/Dip } \\
\text { Direction }\end{array}$ & $\begin{array}{l}\text { Dip } \\
\text { amou } \\
\text { nt }\end{array}$ & $\begin{array}{l}\text { Spacin } \\
\mathrm{g}(\mathrm{cm})\end{array}$ & $\begin{array}{l}\text { Persisten } \\
\text { ce }(m)\end{array}$ & $\begin{array}{l}\text { Apertu } \\
\text { re } \\
(\mathrm{mm})\end{array}$ & $\begin{array}{l}\text { Roughne } \\
\text { ss }\end{array}$ & Infilling & $\begin{array}{l}\text { Weatheri } \\
\text { ng }\end{array}$ & $\begin{array}{l}\text { Grou } \\
\text { nd } \\
\text { Water }\end{array}$ \\
\hline & & al & & & & Planar & material & & \\
\hline J6 & 170 & 50 & $20-60$ & $<5$ & Tight-5 & $\begin{array}{l}\text { Rough, } \\
\text { Undulatin } \\
\text { g }\end{array}$ & $\begin{array}{l}\text { Fragments } \\
\text { of biotite/mi } \\
\text { ca }\end{array}$ & Fresh & Dry \\
\hline $\begin{array}{l}\text { F7a, F7b, } \\
\text { F7c \& F7e }\end{array}$ & 080 & 40 & $15-50$ & $>20$ & Tight-1 & $\begin{array}{l}\text { Smooth, } \\
\text { Undulatin } \\
\mathrm{g}\end{array}$ & $\begin{array}{l}\text { Fragments } \\
\text { of biotite/mi } \\
\text { ca }\end{array}$ & Fresh & Dry \\
\hline F8 & 070 & 48 & $10-130$ & $>20$ & Tight-2 & $\begin{array}{l}\text { Slightly } \\
\text { rough, } \\
\text { Undulatin } \\
\text { g }\end{array}$ & $\begin{array}{l}\text { Surface } \\
\text { stained }\end{array}$ & Fresh & Dry \\
\hline F9a \& F9b & 060 & 70 & $10-100$ & $>20$ & Tight & $\begin{array}{l}\text { Slightly } \\
\text { rough, } \\
\text { Undulatin } \\
\text { g }\end{array}$ & None & Fresh & Dry \\
\hline F10 & 080 & 30 & $10-70$ & $>15$ & Tight-1 & $\begin{array}{l}\text { Rough, } \\
\text { Undulatin } \\
\mathrm{g}\end{array}$ & $\begin{array}{l}\text { Weathered } \\
\text { material }\end{array}$ & Fresh & Dry \\
\hline $\mathrm{J} 11$ & 030 & $\begin{array}{l}\text { Vertic } \\
\text { al }\end{array}$ & $\begin{array}{l}\text { Rando } \\
\mathrm{m}\end{array}$ & $<5$ & 10 & Rough & $\begin{array}{l}\text { Weathered } \\
\text { material }\end{array}$ & Fresh & Dry \\
\hline $\mathrm{J} 12$ & 200 & 60 & $\begin{array}{l}\text { Rando } \\
\mathrm{m}\end{array}$ & $>5$ & Tight & $\begin{array}{l}\text { Rough, } \\
\text { Planar }\end{array}$ & None & Fresh & Dry \\
\hline $\mathrm{J} 13$ & 000 & 60 & 30 & $<2$ & Tight & $\begin{array}{l}\text { Smooth, } \\
\text { Planar }\end{array}$ & $\begin{array}{l}\text { Surface } \\
\text { stained }\end{array}$ & Fresh & Dry \\
\hline J14 & 220 & 60 & $\begin{array}{l}\text { Rando } \\
\mathrm{m}\end{array}$ & $<5$ & Tight & $\begin{array}{l}\text { Rough, } \\
\text { Undulatin } \\
\text { g }\end{array}$ & $\begin{array}{l}\text { Surface } \\
\text { stained }\end{array}$ & Fresh & Dry \\
\hline $\mathrm{J} 15$ & 185 & 30 & $25-45$ & $<5$ & Tight & $\begin{array}{l}\text { Rough, } \\
\text { Undulatin } \\
\text { g }\end{array}$ & $\begin{array}{l}\text { Surface } \\
\text { stained }\end{array}$ & Fresh & Dry \\
\hline J16 & $225-250$ & 60 & $30-40$ & $>10$ & Tight & $\begin{array}{l}\text { Rough, } \\
\text { Undulatin } \\
\text { g }\end{array}$ & $\begin{array}{l}\text { Surface } \\
\text { stained }\end{array}$ & Fresh & Dry \\
\hline J17 & 230 & $\begin{array}{l}\text { Vertic } \\
\text { al }\end{array}$ & $\begin{array}{l}\text { Rando } \\
\mathrm{m}\end{array}$ & $<5$ & Tight & $\begin{array}{l}\text { Rough, } \\
\text { Planar }\end{array}$ & $\begin{array}{l}\text { Surface } \\
\text { stained }\end{array}$ & Fresh & Dry \\
\hline J18 & 180 & 50 & $25-45$ & $<5$ & Tight & $\begin{array}{l}\text { Rough, } \\
\text { Undulatin } \\
\text { g }\end{array}$ & $\begin{array}{l}\text { Surface } \\
\text { stained }\end{array}$ & Fresh & Dry \\
\hline
\end{tabular}

Table 1: Joint recorded in foliated gneiss/granite at the excavated foundation level

The excavated foundation area was falling under weathering grade WI - WII. The grade of the rock mass as 
evaluated from the UCS and conditions of discontinuities has RMR values are varying from 53 to 72 and fall under fair to good rock. The average RMR value is 57 (Table 2). Nearest borehole drilled in the housing chamber area was BH-4. From this borehole, four core samples were tested for the unconfined compressive strength by $\mathrm{M} / \mathrm{s}$ Civil Aid Technoclinic Pvt. Ltd. (Anon, 2009). The uniaxial compressive strength test is primarily an index test for strength classification of rock materials (Table 3).

\begin{tabular}{|c|c|c|c|c|c|c|c|c|c|}
\hline \multirow[b]{2}{*}{ Blocks } & \multirow[b]{2}{*}{$\begin{array}{l}\text { Rock } \\
\text { type }\end{array}$} & \multirow[b]{2}{*}{$\begin{array}{l}\text { UCS } \\
(\mathrm{MPa})\end{array}$} & \multirow[b]{2}{*}{$\begin{array}{l}\text { RQD } \\
(\%)\end{array}$} & \multirow{2}{*}{$\begin{array}{l}\text { Spacing of } \\
\text { discontinuit } \\
y \\
\text { (cm) }\end{array}$} & \multirow{2}{*}{$\begin{array}{l}\text { Condition } \\
\text { discontinuity }\end{array}$} & \multirow[b]{2}{*}{$\begin{array}{l}\text { Ground } \\
\text { water } \\
\text { condition }\end{array}$} & \multirow[b]{2}{*}{$\begin{array}{l}\text { Orientation of } \\
\text { discontinuity }\end{array}$} & \multicolumn{2}{|l|}{ RMR } \\
\hline & & & & & & & & Ratin & Description \\
\hline \multirow[t]{2}{*}{$\begin{array}{l}\text { A, F, K } \\
\& \mathrm{P}\end{array}$} & \multirow[t]{2}{*}{$\begin{array}{l}\text { Foliated } \\
\text { gneiss }\end{array}$} & 56 & $92-95$ & 60 & $\begin{array}{lr}\text { High } & \text { persistence, } \\
\text { rough, } & \text { slightly } \\
\text { weathered } & \end{array}$ & Dry & Unfavourable & \multirow[t]{2}{*}{54} & \multirow[t]{2}{*}{ Fair } \\
\hline & & 7 & 20 & 15 & 12 & 15 & -15 & & \\
\hline \multirow{2}{*}{$\begin{array}{ll}B, & G, \\
H, & M \\
\text { and } & R\end{array}$} & \multirow{2}{*}{ Foliated } & 56 & $92-100$ & 20 & $\begin{array}{l}\text { High persistence, } \\
\text { smooth, unweathered }\end{array}$ & Dry & Unfavourable & \multirow[t]{2}{*}{53} & \multirow[t]{2}{*}{ Fair } \\
\hline & & 7 & 20 & 10 & 16 & 15 & -15 & & \\
\hline \multirow[t]{2}{*}{$\mathrm{C}, \mathrm{I}, \mathrm{O}$} & \multirow{2}{*}{$\begin{array}{l}\text { Foliated } \\
\text { gneiss/ } \\
\text { Granite } \\
\end{array}$} & 56 & $92-100$ & 20 & $\begin{array}{l}\text { High persistence } \\
\text { rough, unweathered }\end{array}$ & Dry & Unfavourable & \multirow[t]{2}{*}{56} & \multirow[t]{2}{*}{ Fair } \\
\hline & & 7 & 20 & 10 & 19 & 15 & -15 & & \\
\hline \multirow[t]{2}{*}{$\mathrm{D}$} & \multirow[t]{2}{*}{$\begin{array}{l}\text { Foliated } \\
\text { gneiss/ } \\
\text { granite }\end{array}$} & 56 & 92 & 25 & $\begin{array}{l}\text { Medium persistence, } \\
\text { tight, } \\
\text { unweathered }\end{array}$ & Dry & Unfavourable & \multirow[t]{2}{*}{62} & \multirow[t]{2}{*}{ Good } \\
\hline & & 7 & 20 & 10 & 25 & 15 & -15 & & \\
\hline \multirow[t]{2}{*}{$\mathrm{E}, \mathrm{J}$} & \multirow{2}{*}{$\begin{array}{l}\text { Foliated } \\
\text { gneiss }\end{array}$} & 56 & $92-100$ & 20 & $\begin{array}{l}\text { High persistence, tight, } \\
\text { rough, unweathered }\end{array}$ & Dry & Unfavourable & \multirow[t]{2}{*}{60} & \multirow[t]{2}{*}{ Fair } \\
\hline & & 7 & 20 & 10 & 23 & 15 & -15 & & \\
\hline \multirow[t]{2}{*}{$\mathrm{L}$} & \multirow[t]{2}{*}{$\begin{array}{l}\text { Foliated } \\
\text { gneiss }\end{array}$} & 56 & 92 & $>200$ & $\begin{array}{l}\text { Low persistence, tight, } \\
\text { slightly rough, } \\
\text { unweathered }\end{array}$ & Dry & Unfavourable & \multirow[t]{2}{*}{72} & \multirow[t]{2}{*}{ Good } \\
\hline & & 7 & 20 & 20 & 25 & 15 & -15 & & \\
\hline \multirow[t]{2}{*}{$N \& S$} & $\begin{array}{l}\text { Foliated } \\
\text { gneiss }\end{array}$ & 56 & $92-98$ & 30 & $\begin{array}{l}\text { Medium persistence, } \\
\text { tight, } \\
\text { unweathered }\end{array}$ & Dry & Unfavourable & 61 & Good \\
\hline & & 7 & 20 & 10 & 24 & 15 & -15 & & \\
\hline Q & $\begin{array}{l}\text { Foliated } \\
\text { gneiss }\end{array}$ & 56 & 92 & 20 & $\begin{array}{l}\text { Medium persistence, } \\
\text { smooth, unweathered }\end{array}$ & Dry & Unfavourable & 55 & Fair \\
\hline & & 7 & 20 & 10 & 18 & 15 & -15 & & \\
\hline $\mathrm{T}$ & $\begin{array}{l}\text { Foliated } \\
\text { gneiss }\end{array}$ & 56 & 89 & 20 & $\begin{array}{l}\text { High persistence } \\
\text { Tight, rough, } \\
\text { unweathered }\end{array}$ & Dry & Unfavourable & 57 & Fair \\
\hline & & 7 & 17 & 10 & 23 & 15 & -15 & & \\
\hline
\end{tabular}

Table 2: RMR-values determined for the excavated foundation floor

\begin{tabular}{|l|l|l|l|l|}
\hline Sr. No & Sample No. & Rock Type & Depth $(\mathrm{m})$ & Uniaxial Compressive Strength (UCS) \\
\hline
\end{tabular}




\begin{tabular}{|l|l|l|l|l|l|}
\hline & & & & $(\mathrm{MPa})$ \\
\cline { 5 - 6 } & & & & Value & Class (ISRM, 1978) \\
\hline 1 & 10 & Granite gneiss & $1.25-2.8$ & 82.9 & Medium Strength \\
\hline 2 & 30 & Foliated gneiss & $9.35-10.25$ & 37.5 & Low Strength \\
\hline 3 & 44 & Foliated gneiss & $14.85-16.40$ & 46.6 & Low Strength \\
\hline 4 & 72 & Foliated gneiss & $19.45-20.08$ & 65.1 & Medium Strength \\
\hline
\end{tabular}

Table 3: Uniaxial compressive strength of core samples

\section{Evaluation of Safe Bearing Capacity}

Safe Bearing Pressure is an important factor for the design of foundation for large engineering structures. The ultimate bearing capacity (q.ult) is defined as average load per unit area required to produce failure by rupture of a supporting rock mass. The bearing capacity in jointed rock masses can be estimated by Rock Types, Rock Mass Rating (RMR), Uniaxial Compressive Strength (UCS), Point Load Strength, Rock Quality Designations (RQD), Pressure Meter Test and Plate Load Test (IS:12070 - 1987, Peck et.al., 1974). The methods based on the Rock Type and Rock Mass Rating (RMR) were used to evaluate the bearing capacity foundation parameters for the foundation of housing chamber. The rock type mapped was fine to medium grained granite/foliated gneiss, and the value of allowable bearing pressure calculated was $500.00 \mathrm{t} / \mathrm{m} 2$ based on rock mass classification. Average Rock Mass Rating (RMR) was taken for the estimation of Allowable Bearing Pressure using the procedure given in IS Code: 12070 - 1987 (Table 4). From the geological point view the allowable bearing pressure value obtained from RMR, that is $257.8 \mathrm{t} / \mathrm{m} 2$ is recommended for the design of foundation on this stratum for housing chamber.

\begin{tabular}{|l|l|}
\hline Based on Rock Type & \\
\hline Rock Type (Material) & Granite, gneiss \\
\hline Net safe bearing pressure (q $\mathrm{ns}$ ) & $1000 \mathrm{t} / \mathrm{m}^{2}$ \\
\hline $\begin{array}{c}\text { Correction factor (for rock mass with continuous joints } \\
\text { with aperture up to 5 mm and weathered/clay filled) }\end{array}$ & 0.50 \\
\hline Allowable bearing pressure (qallow) & $\mathrm{q}_{\mathrm{ns}} *$ correction factor \\
\hline & $1000 * 0.50 \mathrm{t} / \mathrm{m}^{2}$ \\
\hline & $500.0 \mathrm{t} / \mathrm{m}^{2}$ \\
\hline Based on Rock Mass Rating & \\
\hline Average RMR & 57.0 \\
\hline Classification of rock mass & Class III \\
\hline Description of rock mass & Fair \\
\hline Net safe bearing pressure ( $\mathrm{q}_{\mathrm{ns}}$ ) & $257.8 \mathrm{t} / \mathrm{m}^{2}$ \\
\hline $\begin{array}{l}\text { Correction factor (corrections are not applicable for the } \\
\text { classification of RMR method) }\end{array}$ & - \\
\hline Allowable bearing pressure (qallow) & $\mathrm{q}_{\mathrm{ns}} *$ correction factor \\
\hline & $257.8 \mathrm{t} / \mathrm{m}^{2}$ \\
\hline
\end{tabular}

Table 4: Allowable bearing pressure based on rock type and rock mass rating

\section{Discussions and Conclusions}

Based on the field observations and evidences, it was observed that entire floor area is characterized by fine to medium grained, hard and jointed foliated gneiss and granite containing feldspars, quartz and biotite. Depth persistence and lateral prevalence of bed rock was established. The floor region is fresh to slightly weathered but prominent joints were present. Field investigations and assessment indicated that the rock mass is quite competent and acceptable for the foundation. The grade of the rock mass as evaluated from the condition of discontinuities and UCS, has RMR values 
varying from 53 to 72 and falls under fair to good rock mass. Designer has assumed the safe bearing capacity of rock is $40 \mathrm{t} / \mathrm{m}^{2}$ in the design of housing chamber, while based on RMR, recommended allowable bearing pressure value is $257.8 \mathrm{t} / \mathrm{m}^{2}$, which is much higher than the assumed value.

The structural features observed during the mapping indicated that the consolidation grouting up to $6.0 \mathrm{~m}$ should be done in the foundation using primary, secondary and tertiary holes so that the entire floor area functions as a single rock mass. The pressure and proportion of grout mixes to be used for injection shall be based on water pressure test and the results of trial grouting operation. The holes which absorb water greater than 3 lugeons, shall invariable be grouted. The grout holes shall be laid out in line with secondary holes staggered with reference to the primary holes on the adjacent lines. Spacing between holes initially shall be $6 \mathrm{~m}$ centre to centre. After completing the grouting through these primary holes intermediate holes will be taken in between primary holes. The number of holes for further grouting i.e. tertiary grouting - which will be determined based on results of drilling and grouting of intermediate holes, will be such that a continuous consolidated area of satisfactory water tightness is achieved.

It was recommended to complete blasting before taking up grouting operation. If blasting after grouting is unavoidable, through testing and re-grouting will be essential after blasting. Plain Cement Concrete (PCC) of M15 grade lining up to the design foundation level (i.e. RL+659.00 m) should be done before $1000 \mathrm{~mm}$ thick raft foundation. During the foundation treatment, it should be ensured that area is free from water. Care should be taken to remove loosened pieces of rock from the foundation and washing and air jetting should be done so that foundation rests on practically undisturbed rock mass.

Acknowledgements: This work is a part of project sponsored by Ramky Infrastructure Limited, so we sincerely thank the management of RIL for the same. We sincerely thank Director NIRM for permission to publish this manuscript.

\section{References}

1. Anon, Survey investigation. design \& drawing for proposed dam across Markandeya River under Yargol project. Multi Mantech International Pvt. Ltd. Geotechnical Investigation Report 2009;

2. Bieniawski, ZT, Engineering Rock Mass Classification. John Willey and Sons, New York 1989; 251.

3. Harikumar C, Pillai CS, Chetal SC. Foundation floor geological mapping of a nuclear reactor, Geotechnical and Geological Engineering 2010; 28: 503-511.

4. ISO: 12070 (1987): Indian Standard - code of practice for design and construction of shallow foundations on rocks, $13 \mathrm{p}$.

5. ISRM, Suggested methods for the quantitative description of discontinuities in rock mass. Int. Jour. Rock Mech. Sci. and Geomech. (Abstract), Pergamon 1978; 15(6): 319-368.

6. Naithani AK, Singh LG: Geotechnical assessment of a deep surge pool foundation - a case study. ISRM (India) Journal 2016; 5(1) 30-39.

7. Naithani AK, Jain Prasnna, Bhusan Rabi, et al. Geological Mapping of Foundation Floor for Nuclear Building of Rajasthan Atomic Power Project, Rawatbhata, India. Special Publication of the Geological Society of India 2016; 4: 111-118.

8. Naithani AK, Jain JK, Jain Prasnna, et al. Engineering geological investigations of a nuclear building foundation a case study from atomic power project, India. Geosciences Research 2017; 2(1): 14-21.

9. Peck RB, Hanson WE, Thornburn TH. Foundation Engineering, Wiley Publ., New York, 1974; 514p.

10. Radhakrishna BP, Vaidyanadhan R. Geology of Karnataka. Publ. Geological Society of India 2011: 353. 